\title{
Compiling Principles and Standards of ESP Course Books -------Taking English Course Books of Textile Foreign Trade as an Example
}

\author{
ZENG Ru-gang ${ }^{1, \text { a }}$ \\ ${ }^{1}$ Zhejiang Agriculture and Business Polytechnic, Shaoxing, P.R. China, 312000, China \\ a ZENGRugang@yeah.net
}

Keywords: English for specific purposes (ESP); Course books ; Teaching materials; Compiling principles, Standards; Textile foreign trade

\begin{abstract}
The paper studies the existed problems of English of Textile Foreign Trade being compiled, finding out the differences between ESP course books and professional English course books. ESP course books focus on the comprehensive capacity of English practical use in order to use language skills effectively to achieve interpersonal exchange, professional learning in specific workplaces. Its content is related to certain subjects, occupations and activities. Its purpose is to meet the needs of social industry. For the preparation of teaching materials of English of Textile Foreign Trade being compiled, we put forward some compiling Principles and standards of ESP course books by taking occupational skills and ESP courses as centers.
\end{abstract}

\section{Introduction}

With the unprecedented textile industry developments in China, the output of major categories of textile products and foreign trade of textile industry increased dramatically. Shaoxing textile industry is one of major industries gaining rapid growth in China's export in recent years. Shaoxing textile industry has become one of Asia's largest textile market. There is a growing demand on talents with multiple qualifications who are able to use English freely to develop their field work. However, most of the graduates fail to put the language knowledge to the practical use in their work, even though some of them can get a high score in CET tests or even in TOEFL etc. Simply teaching General English(GE) can not better prepare the students for their future work. General English teaching is unable to meet the social needs. English for Specific Purposes(ESP), as a branch of English language teaching(ELT), has been put on the schedule and begins to play a very important role. ESP is a necessary channel to cultivate the talents who are competent in using English to proceed their work. It is a true fact that some achievements have been gained in some aspects of ESP teaching practices, yet it has been pointed out in a lot of papers that current ESP course books have a lot of problems. The issue on compiling Principles and standards of ESP teaching materials is not very much explored. If any, it is either just some theoretical elaborations without particular examples or only case study without theoretical support to fill in this gap, therefore, the paper focuses on how to choose ESP course books based on Shaoxing textile foreign trade and to make a further discussion on compiling principles and standards of ESP course books.

\section{Compilation of ESP course books of textile foreign trade}

\section{a. the existed problems}

The purpose of ESP is to develop learners' comprehensive communication skills including language skills, learning strategies, job skills, related discipline and professional domain knowledge. However, professional English is mainly about professional knowledge in English. ESP teaching is not only aimed at the special use, more of a particular population. Professional English emphasizes the language features in some discipline. The former focuses on the integrated use of English language ability, and the latter focuses on the mastery of the related knowledge and its applications, 
thus, as far as the choice of content, writing style, and learners served are concerned, both are quite different anyway.

On the one hand, from the ESP course books original from abroad, it is obvious that ESP course books can be seldom directly introduced to the universities or the vocational colleges in China and put into the practical use. On the other hand, from the published ESP course books in China, let's take ESP textbook of textile foreign trade as an example, we have already found a lot of such course books as Textile English by Chinese Textile Publishing House, Textile Professional English by Sichuan University Publishing House. Most of them cover the subject of textile raw materials, spinning, weaving (machine weaving, and knitting), non-weaving, dyeing and clothing. The purpose of such course books is specifically for undergraduates and they belong to the discipline research in a sense. Apparently it is not very suitable to take them directly as ESP course books in higher vocational colleges to cultivate the talents who are competent in using English to proceed their professional work.

Strevens (1977) defined ESP courrses as the ones which have determined aims and content, principally or wholly not by criteria of general education but by functional or practical English requirements of the learners. He defined ESP again in 1988 and thought that ESP has four absolute characteristics and two variable characteristics, differentiating it from General English. According to his opinion, absolute characteristics include: firstly, it refers to the English language teaching which is aimed at meeting the specific needs of learners; secondly, its contents are related to certain majors and occupations; thirdly, it focuses on application of language in certain activities related to some majors and professions; fourthly, it is in contrast with General English. Two variable characteristics include: ESP may be restricted to the learning skills to be learned and ESP may not be taught based on pre-ordained methodology. ESP course books focus on the comprehensive capacity of English practical use in order to use language skills effectively to achieve interpersonal exchange, professional learning in specific workplaces. Its content is related to certain subjects, occupations and activities. Its purpose is to meet the needs of social industry. China's Ministry of education and its local educational departments define curriculums in higher vocational colleges as the ones training and improving job abilities for high-skilled talents. In vocational education, English for specific purposes courses aim to cultivate students ' practical ability of using English, focusing on the language communicative competence in the workplace environment.

\section{b. Compiling Principles of ESP course books}

Compilation of ESP course books of textile foreign trade are especially based upon the target situation needs. Target situation needs analysis is the theoretical foundation of ESP and compiling Principles of ESP course books. It focuses on using of language, but it does not simply distinguish linguistic features in target situation. Target situation needs analysis can make people understand what English will be used for and what knowledge and skills learners have acquired. Target situation needs analysis can help us gather the information about principle knowledge, skills, strategies, etc. The choice of teaching materials should not only rely on the target situation needs analysis, but also rely on the combination of professional knowledge and the real language environment. Therefore ESP course books of textile foreign trade is mainly based on working process: the design of each unit strictly matched with the beginning and end of textile foreign trade business activities. Its contents is related to certain working experiences and coping strategies of real cases.

Taking Shaoxing textile industry as an example, listening materials of ESP course books of textile foreign trade should be authentic. We have a lot of different accents from the Middle East, Africa, South America and other countries. If we teach students with American English or British English accents, it may slow down the students' listening abilities in real business talk. What's more, businessmen from different countries may have different way of thinking and different customs. Therefore, ESP course books in high vocational colleges should focus on " how to do it" and " what to do". "why to do it" is not the key problem. The choice of teaching materials is around the steps of working process and the application of knowledge rather than the memory of it. The difficulty level of the materials often determines the compilation of ESP course books by the teachers and experts 
in colleges which is completely in accordance with the real occasion in China. The introduction of ESP course books from abroad into China is not a good way if they are directly used without any modification. The compilation of ESP course books must be a tendency in vocational colleges in the near future. So compiling principles of ESP course books are as follows: 1) Authenticity. The materials should be authentic, meeting students' learning needs and facilitating their understanding. Besides, the materials should be real-life related, that is to say, to convey the development tendency of the textile industry. It may arouse students' learning interest greatly. The materials should focus on training or developing students' communicative competence in order to meet their needs for job hunting and further study.2) Appropriateness. The difficulty level of the materials should be in accordance with students' English proficiency. If the materials are beyond students' proficiency, they may feel discouraged and frustrated. But if the materials are too simple to students, it is difficult to attract students' attention. Thus, it is important to make sure that the difficulty level is in accordance with the students' English proficiency. The difficulty of teaching materials should be slightly higher than the current level of the learners (i+1). The new knowledge will be available only when the learners have mastered and formed their "old" knowledge. This is so called the balance between input and output.3) Compatibility. Compatibility refers to the relationship between the materials and contents of the course should be compatible. The ESP course is aimed at cultivating students' abilities of using English to deal with specialized situation. To achieve the teaching target, the materials in each unit should be well designed.4) Enjoyment. Appropriate teaching materials should be of certain interesting. This can be seen not only from its contents but also from its implementation style. Good materials can arouse students' learning interest and achieve desired teaching sequences. In a word, compiling principles should be authentic, appropriate, compatible, full of fun. Such ESP course books can meet the real needs of the colleges and can be taken as good teaching materials to cultivate the talents who are qualified with the posts without the learning adaptation.

\section{Standards of ESP course books of textile foreign trade}

College English is traditionally taught under the guidance of the syllabus and all college English textbooks have to be in line with the details of the syllabus. However, there is no such syllabus for ESP course books as guidance and no teaching, compiling and evaluation theory to support them. Many colleges still organize teachers and experts to compile ESP course books. Their quality varies greatly and has a huge influence on compiling ESP course books. Therefore, it is urgent for colleges to set standards of ESP course books to guide how to compile them. It is of great significance.

In order to study the standards of ESP course books, we have firstly analyzed course books evaluation theory and evaluation methods. Many foreign evaluation experts studying course books take evaluation and questionnaires of different teachers and learners combined before they make a final decision. The means of evaluating course books is quite popular. Of course it is based upon the opinions and feedbacks collected from questionnaires about the course books. To design a good questionnaire and perfect it consume a lot of energy and time. There also exists some problems about the validity and reliability of a questionnaire. Accordingly, the problem for the result of the evaluation of course books may arise. Therefore, the criteria for course books evaluation should be flexible on various occasions, let alone cover all aspects of the content of teaching materials concerned.

Here are some standards for ESP course books of textile foreign trade. (1) high-quality ESP course books for vocational colleges should be used for several periods. It needs improving and modifying and then further improvements should be made to "bridge the gap" out of practice. Simple combinations of English language with textile professional knowledge can't make a good ESP course book for textile foreign trade.(2) Teacher's role is an important issue in compiling ESP course books. According to Dudley-Evans and St. John (1998), roles of ESP teachers can be divided into five types: teacher, course designer and supplier, cooperator, researcher, and assessor. They can cooperate to study the contents and teaching methods, even to discuss the methods of evaluating the abilities of students. (3) The compilation of ESP course books and teaching methods should be 
closely linked to realize the practice of real case analysis and real communications with the abilities-centered cultivation. Cases, class activities and exercises should be elaborately designed in each unit. We should transfer the communication knowledge to communication skills, cases to the skills to handle them.(4) The corpus of ESP course books of textile foreign trade should be established. Qian Yuan put it like this in 1995: “ how to make good use of computers to complete language project handling work is the urgent problem to be solved. " We can establish a corpus for words, phrases, useful expressions, dialogue in authentic language environment, profession knowledge, the mode of practical operations and so on through computers. By cooperating with industry experts, graduate students, seminars can be held to get questionnaires to analyze and perfect the corpus of ESP course books of textile foreign trade.

\section{Conclusion}

By analyzing ESP course books of textile foreign trade, we have a whole-new idea of how to compile ESP course books. Its purpose is to cultivate the talents who are competent in using English to proceed their work to meet the demand of the society for talents in China. However, the investigation of ESP course books for students majoring in textile is definitely a valuable research and is worth being noticed. Of course, it has been pointed out that the research has a lot of other problems deserving noticing. After all, ESP teaching is one of the development tendency of the reform of college English teaching in China, reflecting the current trend of curriculum reform of vocational education in our country.

\section{References}

[1] Breen, M. \& Candlin, C. Which materials? A consumer's and designer's guide [A]. In L.E.Sheldon (ed). ELT Textbooks and Materials: Problems in Evaluation and Development [C].London: Modern English Publications, 1987:14-28.

[2] Canale, M. and Swain, M. Theoretical Bases of Communicative Approaches to Second Language Teaching and Testing[ J] . Applied Linguistics. 1980( 1): 1- 47.

[3] Cunningsworth, A. Selecting \& Evaluating EFL Teaching Materials [M]. London: Heinemann,1984.

[4] Cunningsworth, A. Choosing Your Coursebook [M]. Oxford: Heinemann, 1995.

[5] Dudley-Evans, T. \& St. John. Development in English for Specific Purposes [M]. Cambridge: Cambridge University Press,1998.

[6] Hutchinson, T. \& Waters, A. English for Specific Purposes: A Learning-centered Approach [M].Cambridge: Cambridge University Press, 1987.

[7] Hyland, K. Specificity Revisited: How Far Should W e Go Now? [ J]. English for Specific Purposes, Vol. 21, Issue,4, 2000: 385- 395. 